\title{
ANNA ALICHNIEWICZ
}

\section{ŚMIERĆ MÓZGOWA: KONTROWERSJE I UZGODNIENIA**}

Słowa kluczowe: śmierć organizmu jako całości, śmierć osoby, śmierć mózgowa, całkowita niewydolność mózgu, definicja śmierci, kryteria śmierci

Keywords: death of the organism as a whole, death of a human person, brain death, total brain failure, definition of death, criteria of death

\section{Wstęp}

Jahi McMath była trzynastoletnią dziewczynką, gdy 9 grudnia 2013 przeprowadzono u niej zabieg wycięcia migdałków oraz fragmentów podniebienia miękkiego i gardła w związku z napadami bezdechu nocnego. Był to dość rozległy i skomplikowany zabieg, jednak z pewnością nieprzewyższający kwalifikacji doświadczonego zespołu chirurgicznego renomowanego

* Anna Alichniewicz - adiunkt w Zakładzie Bioetyki Uniwersytetu Medycznego w Łodzi. Jej zainteresowania badawcze dotyczą filozofii współczesnej i bioetyki, zajmuje się głównie fenomenologią cielesności, tanatologią filozoficzną i bioetyczną oraz analizą stereotypów genderowych w dyskursie bioetycznym i biomedycznym.

Address for correspondence: Medical University of Lodz, Faculty of Health Science, Chair of Humanities, Department of Bioethics, Lindleya 6, 90-131 Lodz. E-mail: anna. alichniewicz@umed.lodz.pl.

** Publikacja w ramach projektu badawczego nr 2015/19/B/HS1/00996 finansowanego przez Narodowe Centrum Nauki. 
UCSF Children's Hospital w Oakland. Pacjentka dobrze zniosła operację i nic nie zapowiadało tragedii. Niestety kilka godzin po zabiegu pojawiło się intensywne krwawienie z nosa i ust, które doprowadziło do zatrzymania pracy serca. Została zaintubowana, ale przywrócenie pracy serca i ustabilizowanie oddechu zajęło lekarzom dwie i pół godziny. Po dwóch dniach przeprowadzone testy potwierdziły diagnozę śmierci mózgowej. Stosując się do obowiązującej w Kalifornii wersji Uniform Determination of Death Act, stwierdzono zgon. Jahi McMath nie odłączono od razu respiratora, gdyż przepisy stanowe nakazują pozostawienie rodzinie krótkiego czasu na pożegnanie. Ale do pożegnania nigdy nie doszło. Rodzina stanowczo sprzeciwiła się odłączeniu respiratora i zażądała sztucznego odżywiania. Szpital zdecydowanie odmówił, gdyż wykonywanie czynności leczniczych na zwłokach jest niezgodne z etyką i profesjonalizmem lekarskim. Sprawa trafiła do sądu, w którym zawarto niezwykłą ugodę: szpital zgodził się wydać ciało Jahi McMath koronerowi, który 3 stycznia 2014 roku wystawił akt zgonu, a jako przyczynę śmierci wpisał: „w trakcie wyjaśniania”. Dwa dni później dziewczynka została zabrana nieoznakowanym ambulansem i przetransportowana do stanu New Jersey, jednego z dwóch, obok stanu Nowy Jork, amerykańskiego stanu, w którym można wyrazić niezgodę na diagnozowanie śmierci kryteriami neurologicznymi. Prawo to w założeniu dotyczy wyznawców ortodoksyjnego judaizmu, jednak w tym wypadku skorzystała z niego rodzina, która uważa się za chrześcijan, i Jahi McMath została przyjęta do katolickiego szpitala uniwersyteckiego w Nowym Brunszwiku. Jeden z chirurgów wykonał tracheotomię, podłączono też sondę odżywiającą, ale znaczna część personelu szpitala była przeciwna przeprowadzaniu tych działań na zwłokach. Niemniej przez następne osiem miesięcy Jahi przebywała w szpitalnym oddziale intensywnej terapii, a koszt opieki wynoszący 150 tysięcy dolarów tygodniowo pokrywał Medicaid, czyli federalny program pomocowy finansujący opiekę medyczną osobom, które nie są w stanie za nią zapłacić. W końcu sierpnia 2014 roku pacjentkę wypisano ze szpitala z rozpoznaniem śmierci mózgowej. Rodzina wynajęła małe mieszkanie i tam Jahi McMath przebywała przez następne cztery lata, a Medicaid opłacał koszt całodobowej opieki pielęgniarskiej. Ponieważ zgodnie z prawem stanu Kalifornia Jahi nie żyła od 9 grudnia 2013 roku, a zwłoki nie mogą być przetrzymywane w domu, rodzina nie mogła wrócić do Oakland. Matka Jahi, Nailah Winkfield, próbowała skarżyć Oakland Children's Hospital o błąd w sztuce oraz uzyskać sądowe uchylenie aktu 
zgonu swej córki. Zanim jednak jej zabiegi odniosły jakikolwiek skutek, prawnik rodziny ogłosił, że Jahi McMath zmarła 22 czerwca 2018 roku wskutek krwawienia spowodowanego niewydolnością wątroby. Zapowiedział też, że będzie kontynuował działania na rzecz unieważnienia wcześniej wydanego aktu zgonu oraz uznania 22 czerwca 2018 za datę jej śmierci.

Tragiczny przypadek Jahi McMath stanowi znakomitą ilustrację głównych problemów, jakie pojawiają się w dyskusji o śmierci mózgowej. Po pierwsze jest to kwestia relacji między diagnozą śmierci organizmu jako całości wskutek śmierci mózgu a stwierdzeniem zgonu pacjenta, a więc śmierci osoby, nawet jeśli mówi się o osobie bez jakichkolwiek konotacji metafizycznych, rozumiejąc ją jako „Ja” psychofizyczne, czy też - jak proponuje Paweł Łuków - jako osobę o biologii Homo sapiens (Łuków, 2015). Po drugie jest to kwestia tego, co rozumiane jest pod pojęciem, ,śmierć mózgowa". Problem ten odnoszony jest do dwóch poziomów rozważań: poziomu filozoficznego, dotyczącego ontologicznej natury śmierci, oraz poziomu biomedycznego, gdzie pojawia się pytanie, czy śmierć jest zdarzeniem, czy też ma charakter procesualny. Z zagadnieniem tym bezpośrednio wiąże się trzecia sporna kwestia, to znaczy, co właściwie jest przedmiotem diagnozy: śmierć mózgu czy też pewien jego stan, który interpretuje się jako równoważny śmierci. Kolejnym wzbudzającym kontrowersje problemem są kryteria, które należy przyjąć dla diagnozowania śmierci mózgowej.

Trwająca od kilku dekad dyskusja wokół tych zagadnień przyniosła obfitą i stale rosnącą literaturę, co stawia podejmującego tę problematykę autora w dość trudnej sytuacji - nie sposób bowiem odnieść się do całego piśmiennictwa, trudno też powiedzieć coś zdecydowanie nowego. Nie pretendując do oryginalności ani też całościowego przeglądu literatury, chcę uporządkować główne, moim zdaniem, problemy i rzucić na nie nieco inne światło, stawiając następujące tezy:

1. Pojęcie śmierci w gruncie rzeczy nie poddaje się definicji.

2. Funkcję definicji śmierci pełnią de facto jej kryteria.

3. W debacie odnoszącej się do tzw. definicji śmierci nie chodzi o śmierć jako taką, pojętą uniwersalnie, lecz o śmierć człowieka.

4. Analizując śmierć człowieka, nie sposób ściśle odróżnić płaszczyznę biologiczną i filozoficzną (ontologiczno-aksjologiczną).

Tezy te postaram się szerzej przedstawić i uzasadnić w kolejnych podrozdziałach. 


\section{Kłopotliwe pojęcie śmierci - definicja czy kryteria?}

Filozoficzna analiza pojęcia śmierci napotyka szereg trudności. Przede wszystkim pojawia się pytanie, jak można zdefiniować śmierć? Definicja dotyczy przedmiotu, stanu, zdarzenia lub procesu, których naturę ma za zadanie uchwycić. Jak jednak scharakteryzować przedmiot „śmierć”? Czy jest to proces? Procesem jest raczej umieranie, czy zatem śmierć jest zdarzeniem lub stanem? Jeśli rozumieć ją jako zdarzenie, to ma ono charakter graniczny, oddzielający to, co żywe, od tego, co martwe, czyli w wypadku człowieka: „Ja” od „nie-Ja”. Jeśli natomiast próbować zrozumieć śmierć w kategoriach stanu, to należy zauważyć, że śmierć nie jest stanem, lecz właśnie jego brakiem lub nawet radykalną niemożliwością bycia w jakimkolwiek stanie, bowiem być w jakimkolwiek stanie może tylko coś, co jest, co bytuje, a w wypadku organizmu żywego - co żyje. Stan można więc rozpatrywać jako jeden z modi egzystencji: możemy zatem mówić o stanie zdrowia, stanie choroby itd., ale nie o stanie śmierci. Jako zaprzeczenie egzystencji ma ona negatywny status ontologiczny. Ta prywatywna natura śmierci odnosi do braku życia, które jednak równie niełatwo poddaje się definiowaniu. Trudności dotyczące pojęcia śmierci organizmu jako takiego nabierają szczególnego znaczenia, gdy mówimy o śmierci człowieka, u którego na warstwie ontycznej nabudowuje się sens biologiczny, a także kolejne sensy osobowe: psychologiczny, społeczny i prawny.

Jako problem biomedyczny śmierć przysparza nie mniejszych kłopotów, gdyż w tym wypadku należałoby odnieść się nie tylko do pojęcia i jego definicji, ale także kryteriów rozpoznawania śmierci i testów diagnostycznych mających na celu sprawdzenie, czy kryteria te są spełnione. Wszystkie te zagadnienia wiążą się z trudnościami natury teoretycznej i praktycznej. Mimo że uznaje się potrzebę sformułowania biologicznej definicji śmierci, to jednak, jak zobaczymy, proponowana definicja wskazuje, że i tu również przedmiot pozostaje nieuchwytny. Przede wszystkim należy zauważyć, że pojęcie śmierci może odnosić się do kilku poziomów:

1. Śmierci poszczególnych części organizmu.

2. Śmierci całego organizmu.

3. Śmierci organizmu jako całości, która może być rozumiana

a) jako śmierć krążeniowo-oddechowa (nieodwracalne ustanie krążenia i oddychania); 
b) jako śmierć całego mózgu (nieodwracalne ustanie funkcji całego mózgu);

c) jako śmierć mózgu jako całości wskutek śmierci pnia mózgu (nieodwracalne ustanie funkcji pnia mózgu);

d) jako śmierć „wyższego mózgu” (nieodwracalna utrata zdolności świadomości).

4. Śmierci osoby.

Istnieje dość szeroki konsensus, że z biologicznego punktu widzenia pojęcie śmierci należy definiować jako ustanie funkcjonowania organizmu jako całości (Miller, Truog, 2012, s. 64). Poglądy na to, co pod takim ustaniem funkcjonowania należy rozumieć, ewoluują, można jednak zauważyć, iż mimo że prezentowane jako definiens, proponuje się w istocie ogólne kryterium śmierci. Biorąc pod uwagę nieuchwytność definiendum, którego prywatywna natura odsyła do również niedefiniowalnego pojęcia życia, gdzie także mamy do czynienia raczej z kryterium funkcjonowania jako całość niż definicją w sensie ścisłym, jest to zapewne najlepsze dostępne teoretycznie sformułowanie. Zatem faktu, że pod nazwą „,definicja śmierci” w gruncie rzeczy funkcjonuje zbiór kryteriów nie należy, moim zdaniem, traktować jako słabości czy niedociągnięcia teoretycznego, gdyż granice definiowalności określa tu ontyczna natura przedmiotu. Dlatego też, mimo tych zastrzeżeń, w dalszej części swoich rozważań będę używać przyjętego terminu ,definicja śmierci”.

Kryterium ustania funkcjonowania organizmu jako całości podlega następnie uszczegółowianiu do nieodwracalnego ustania krążenia i oddychania albo nieodwracalnego ustania funkcji całego mózgu lub pnia mózgu. Propozycja, aby śmierć człowieka rozumieć jako nieodwracalną niezdolność świadomości, czyli śmierć tzw. wyższego mózgu, nie znalazła akceptacji i nigdzie nie stała się podstawą oficjalnie przyjętej definicji śmierci. Nigdy też nie postulowano, by śmierć człowieka ujmować jako śmierć całego organizmu, czyli stan, gdy wszystkie elementy ciała są martwe, gdyż oznaczałoby to oczekiwanie na jego rozkład, aczkolwiek w przeszłości wielu lekarzy traktowało rozkład ciała jako jedyną pewną oznakę śmierci (Pernick, 1988, 20-21). Kryteria śmierci mózgowej dotyczą tylko człowieka, co zdaniem przeciwników tego pojęcia stanowi jego słabość (Miller, Truog, 2012, s. 67 -71), zwolennicy wskazują natomiast, że świadczy to właśnie o jego szczególnej adekwatności do diagnozowania śmierci człowieka (Lee, 2016). 
Czy w sensie biomedycznym śmierć jest procesem czy zdarzeniem? Jeśli jest procesem, to zaczyna się wówczas, gdy jeszcze trwa życie, którego jest przecież zaprzeczeniem. Jeśli jest zdarzeniem, to jak je uchwycić, skoro zjawiska biologiczne mają charakter procesualny? Mogło się wydawać, że przydatne okaże się tu pojęcie progu oddzielającego ,,proces umierania od procesu dezintegracji” (Bernat, Culver, Gert, 1981, s. 389), jednak badania medyczne i praktyka kliniczna wykazały, że w wypadku śmierci mózgowej proces dezintegracji bywa poważnie odroczony. Miller i Truog proponują rozumienie śmierci jako zdarzenia w kategoriach termodynamicznych: byłaby momentem, w którym organizm nieodwracalnie przestaje się opierać procesom entropii. Autorzy zauważają jednak, że choć jest to moment konceptualnie uchwytny, jego empiryczne wyznaczenie zapewne pozostanie niemożliwe (Miller, Truog, 2012, s. 70; Nair-Collins, 2018, s. 33-34). Tym, co wydaje się wspólne dla wszystkich prób biomedycznego zdefiniowania śmierci, jest dążenie do uchwycenia momentu nieodwracalności (point of no return). Jeśli nawet rozumie się śmierć jako stan kliniczny (Becler, 2015, s. 60), to jest to również stan nieodwracalny (Belkin, 2014, s. 84).

\section{Debata wokół definicji śmierci}

Uważa się, że przynajmniej od pewnego momentu w ewolucji (Clark, 2000) śmierć dotyczy wszystkich organizmów żywych, można by zatem przypuszczać, że związane z jej pojęciem trudności ontologiczno-definicyjne mają wymiar uniwersalny. Jednak debata wokół definicji śmierci odnosi się wyłącznie do śmierci człowieka. Dzieje się tak zapewne ze względu na występujące tu napięcie między pojęciem śmierci organizmu jako całości, które przynajmniej w założeniu odnosi się do kategorii biomedycznych, a konotacjami psychologicznymi, społecznymi i prawnymi, wiążącymi się z pojęciem śmierci osoby. Od pewnego zaś czasu szczególne kontrowersje wzbudza pojęcie śmierci mózgowej, choć wprowadzona w 1968 roku Raportem Harwardzkim pierwsza w historii jej definicja początkowo nie wywołała większego sprzeciwu. Peter Singer nazwał ją nawet ,przewrotem bez opozycji” (Singer, 1997, s. 38). Jednak stopniowo opór narastał. Wydaje się, że wiązało się to przede wszystkim z dwoma, niekoniecznie trafnymi zarzutami. Po pierwsze w wielu komentarzach akcentowano znaczenie nieodwracalnej utraty świadomości dla diagnozy śmierci mózgowej 
(Singer, 1997, s. 36-42; Pernick, 1998, s. 58; Miller, Truog, 2012, s. 68), chociaż raport Nadzwyczajnej Komisji Harwardzkiej Szkoły Medycznej do Zbadania Definicji Śmierci Mózgowej (Ad Hoc Committee of the Harvard Medical School to Examine the Definition of Brain Death) z 1968 roku, podając nieodwracalną śpiączkę jako nowe kryterium śmierci, wyraźnie podkreślał, że stosuje się ono jedynie wobec pacjentów, u których nie stwierdza się czynności ośrodkowego układu nerwowego. Drugim zarzutem było uznanie, że definicję śmierci mózgowej wprowadzono, by ułatwić pobieranie narządów do transplantacji. Jest to dość powszechna opinia, a jej zwolennicy powołują się na korespondencję Henry’ego Beechera (późniejszego przewodniczącego Komisji Harwardzkiej) z Robertem Ebertem (ówczesnym dziekanem Harvard Medical School), a także na wypowiedź Beechera, podkreślającą znaczenie nowej definicji śmierci dla pobierania nadających się do przeszczepienia narządów (Singer, 1997, s. 33-36; Belkin, 2014, s. 67). Jednak Gary Belkin w swej książce poświęconej kulisom Raportu Harwardzkiego, nie negując wprawdzie uwagi Beechera o znaczeniu definicji śmierci mózgowej dla transplantologii, podkreśla zarazem, że wypowiedź ta wskazywała jedynie na skutki nowej definicji dla tej dziedziny, a nie na przyczyny jej sformułowania (Belkin, 2014, s. 69, 173).

Z drugiej strony pojawiły się także opinie, że sformułowana w Raporcie Harwardzkim definicja śmierci mózgowej jest nie dość radykalna i że za kryterium śmierci człowieka powinno się przyjąć nieodwracalną utratę świadomości. Koncepcja ta, znana jako śmierć „wyższego mózgu”, której zwolennikiem jest na przykład Robert Veatch $(1988,1993)$, nie znalazła jednak szerszego poparcia i została odrzucona w opublikowanym w 1981 roku raporcie amerykańskiej Komisji Prezydenckiej, zatytułowanym Defining Death (President's Commission for the Study of Ethical Problems in Medicine and Biomedical and Behavioral Research, 1981), a następnie w Uniform Determination of Death Act (1981), który wprowadzał podstawę prawną orzekania śmierci dla wszystkich stanów USA. Opowiadając się za definiowaniem śmierci mózgowej jako nieodwracalnego ustania funkcji całego mózgu, w tym pnia mózgu, Komisja potwierdziła wartość kryteriów neurologicznych, podkreślając integrujące znaczenie mózgu dla organizmu jako całości. Warte zauważenia jest to, że w dokumencie tym mówi się o funkcjach, a nie - jak w Raporcie Harwardzkim - czynnościach mózgu. Podejście to, które Singer nazywa liberalizującym (Singer, 1997, s. 245), wynikało jednak nie z takiej czy innej postawy etycznej, 
lecz z danych uzyskanych w intensywnie rozwijających się dyscyplinach neurobiologicznych i klinicznych, wskazujących na mniejsze znaczenie trwania czynności bioelektrycznej czy metabolicznej w grupach komórek mózgu dla kryteriów śmierci mózgowej. Podobnie za nieistotne dla rozpoznania śmierci mózgowej uznano funkcje rdzenia kręgowego, które mogą przejawiać się tak spektakularnym objawem, jak odruch Łazarza (Miller, Truog, 2012, s. 56-57).

Dalsze etapy rozwoju nauk biomedycznych i praktyka kliniczna, wykazujące względną niezależność różnych funkcji organizmu, podważyły zasadność rozumienia mózgu jako niezbędnego integratora całości somatycznej. Okazało się, że do nieodwracalnego zatrzymania krążenia u podłączonego do respiratora pacjenta ze zdiagnozowaną śmiercią mózgową może dojść dopiero po tygodniach, miesiącach, a w rzadkich przypadkach nawet po latach. Możliwe jest utrzymanie ciąży, goją się rany, zwalczane są infekcje i trwa hemopoeza, a w wypadku dzieci i młodzieży dochodzi do wzrostu ciała i dojrzewania płciowego (Becler, 2015, s 61-62; Miller, Truog, 2012, s. 65-66). Niektóre z tych zjawisk ilustruje opisany we wstępie przypadek Jahi McMath (Truog, 2018). Dane te stały się podstawą empiryczną następnego ważnego dokumentu odnoszącego się do śmierci mózgowej, tzw. White Paper, opublikowanego w 2008 roku przez President's Council of Bioethics (2008). Opracowanie to zrywa z wcześniejszą koncepcją śmierci mózgowej jako utratą zintegrowanego funkcjonowania organizmu jako całości i wprowadza pojęcie całkowitej niewydolności mózgu (total brain failure). Organizm w tym stanie niezdolny jest do wykonywania niezbędnych funkcji życiowych, to znaczy do odbierania płynących z otoczenia bodźców i reagowania na nie, do posiadania zdolności uzyskiwania ze świata tego, co jest dla niego niezbędne, oraz do tego, by jego napęd stanowiło odczuwanie potrzeby takiego działania. Jest to nowy język, jednak sens pozostaje ten sam: całkowita niewydolność mózgu jest nowym kryterium śmieci mózgowej. Jednocześnie proponuje się tu takie rozumienie organizmu żywego, które pozwala na odparcie argumentu, że o życiu decyduje samo trwanie funkcji, a nie jej mechanizm (Miller, Truog, 2012, s. 70). 


\section{Płaszczyzna biologiczna i filozoficzna}

Zajmujący się problematyką śmierci autorzy zauważają wspomniane napięcie między śmiercią organizmu a zgonem osoby i, choć można spotkać opinię, że śmierć powinna być traktowana jako fenomen wyłącznie biologiczny (Bernat, 2002; Marquis, 2018), to jednak przeważa pogląd, wyrażany na przykład przez Johna Lizzę, że w jej definiowaniu należy wyjść poza kategorie czysto biologiczne (Lizza, 2018). Zarówno Lizza, jak i Shewmonowie (Lizza, 2008; Shewmon, Shewmon, 2004) mówią o różnicy między śmiercią organizmu a śmiercią osoby, nawet jeśli odmiennie sytuują ich miejsca na procesualnym continuum biologicznym (Lizza, 2008, s. 9). Niemniej nawet jeśli dostrzega się wpływ uwarunkowań pozabiologicznych na pojęcie śmierci organizmu (Lizza, 2018, 14), to jednak pojęcia te traktuje się jako odrębne, proponując ,semantyczne bifurkacje” na śmierć organizmu i śmierć osoby lub śmierć biologiczną i śmierć cywilną (Lizza, 2018, s. 6). Uznanie wpływu uwarunkowań społecznych i kulturowych na pojęcia i kategorie biologiczne jest dzisiaj, po pracach chociażby Canguilhema (1994, 2000, 2012), konstatacją banalną, ale sądzę, że w wypadku kryteriów śmierci człowieka problem sięga głębiej. Przede wszystkim należy zauważyć, że mamy tu do czynienia nie tyle z poziomem ogólnych rozważań biologicznych, ile biomedycznych, zaś dyskurs medyczny jako dotyczący człowieka jest szczególnie podatny na wpływy pozabiologiczne. Zdaniem Engelhardta (1966) rzeczywistość medyczna kształtowana jest przez jej cztery języki: deskryptywny, ewaluacyjny, eksplanacyjny i społeczny. Języki te nakładają się na siebie i wzajemnie przenikają, określając przedmiot nauk biomedycznych zarówno na poziomie teoretycznym, jak i praktyki klinicznej. Dlatego też w rozważaniach dotyczących śmierci człowieka niemożliwe wydaje mi się ścisłe odróżnienie płaszczyzny biologicznej i filozoficznej, czyli ontologiczno-aksjologicznej. Sposób definiowania osoby ludzkiej jako „Ja” psychofizycznego czy też jako bytu określonego metafizycznie dostrzegalny jest już na poziomie medycznego orzekania śmierci organizmu. Jeśli osoba ludzka jest pojęta metafizycznie jako ufundowana przez obecność duszy, to relacja duszy i ciała ma także konsekwencje dla sposobu określania biologicznego fenomenu życia. Zdeterminowany przez kartezjanizm zachodni sposób myślenia o człowieku na ogół utożsamia czynnik psychiczny z umysłem, a ten sytuuje w mózgu, natomiast sprzeciw wobec kryteriów neurologicznych, a tym samym nieuznawanie 
śmierci mózgowej przez ortodoksyjne odłamy judaizmu czy buddyzmu, wynika z koncepcji duszy jako czynnika życia wszechprzenikajacego ciało człowieka. Przejawem duszy jest oddech, zatem tak długo jak trwa oddychanie, osoba pozostaje żywa. Tak więc fakultatywny charakter kryteriów neurologicznych, przyjęty przez prawo stanów New Jersey i Nowy Jork oraz przez japońską ustawę transplantologiczną, wynika z innej niż to ma miejsce w kartezjańskiej tradycji zachodniej koncepcji relacji duszy i ciała (Zeiler, 2009). Niewątpliwie przyjęcie definicji śmierci mózgowej pozostaje w zgodzie z tradycją kultury zachodniej, identyfikującej istotę człowieka z duszą, a następnie z psychiką i jej materialną podstawą, czyli mózgiem. Mózg tym samym zyskuje szczególne znaczenie i zostaje wyodrębniony z ciała, którego część przecież stanowi (Leder, 1990; Edwards, 1998). Dlatego też można mieć wątpliwości, czy rzeczywiście - jak twierdzi Belkin (2014, s. 163-164) - wyłącznie praktyka kliniczna z pacjentami w stanach głębokich zaburzeń świadomości i dane empiryczne wskazujące na brak szans przeżycia w ich w przypadku, a nie również pewne założenia filozoficzne dotyczące istoty człowieczeństwa, doprowadziły do sformułowania definicji śmierci mózgowej.

Czy ewolucja, jaką przechodzi pojęcie śmierci mózgowej i kryteria, które stanowią de facto jej definicję, świadczą o słabości tej koncepcji? Twierdzenie takie wynikałoby z niezrozumienia epistemologii medycyny i natury faktów medycznych, które w większości są „względne i konceptualnie niechlujne” (Belkin, 2014, s. 227) oraz przeważnie mają charakter operacyjny: są zdeterminowane przez skutki (Belkin, 2014, s. 225). Wprowadzenie respiratora umożliwiającego podtrzymywanie oddechu u pacjentów nieodwracalnie niezdolnych do samodzielnego oddychania stworzyło nową rzeczywistość, w której zasadne stało się definiowanie śmierci człowieka jako śmierci mózgu, zwłaszcza że pozostaje ono w zgodzie z pewną tradycją rozumienia osoby ludzkiej. Założenia filozoficzne zawsze kształtowały sposób myślenia o życiu i śmierci człowieka w dyskursie biomedycznym, ale nowa technologia medyczna stworzyła możliwość wyciągnięcia z nich pewnych konsekwencji praktycznych. W tym sensie można powiedzieć, że wiedza medyczna nie tylko opisuje mechanizmy biologiczne, ale i nimi manipuluje. Dotyczy to jednak wielu, jeśli nie wszystkich faktów medycznych, i „fakt” śmierci 
mózgowej nie jest w tym sensie niczym wyjątkowym, lecz wykazuje taką samą ewolucję, jak na przykład pojęcie i kryteria nadciśnienia (Belkin, 2014, s. XXVI). Z drugiej strony można dostrzec, że fakty te są także pewnymi konstruktami społeczno-kulturowymi, odzwierciedlającymi różne języki medycyny, a więc panujące przekonania dotyczące normalności, patologii, zdrowia, choroby, akceptowanego wyglądu ludzkiego ciała itd. Oczywiste jest jednak, że żadne pojęcie medyczne nie wzbudza takich kontrowersji, jak pojęcie śmierci mózgowej, ponieważ mamy tu do czynienia ze szczególnie mocnym napięciem między - przynajmniej deklaratywnie - czysto biologicznie zdefiniowanym organizmem, którego dotyczy diagnoza śmierci, a nasyconym aksjologicznie pojęciem osoby, której zgon - ze wszystkimi konsekwencjami społeczno-prawnymi - się stwierdza. Technologia medyczna wyostrza paradoksalny charakter ludzkiej cielesności, polegający na tym, że zarazem jesteśmy naszym ciałem i je mamy. Śmierć mózgowa jest ponadto nieintuicyjna w tym sensie, że uchwytny dla współczesnej medycyny fakt całkowitej niewydolności mózgu jest niezgodny z potocznym wyobrażeniem zwłok.

Z punktu widzenia filozofii śmierć jest nieuchwytnym Graalem, skazującym na fiasko wszelkie próby znalezienia ścisłych wykładników empirycznych, które odpowiadałyby pojęciom należącym do kategorii ontologiczno-egzystencjalnych. Z punktu widzenia biologicznego jest to punkt bez powrotu, w którym nieodwracalnie ustało życie. Niemożliwość precyzyjnego uchwycenia tego punktu wynika nie tylko stąd, że procesy biologiczne mają charakter kontinuów, ale także z tego, że różne procesy zanikają w różnym czasie i że nadal jest przedmiotem dyskusji, o jakich procesach biologicznych należy tu mówić. Zatem kontrowersje wokół definicji śmierci to nie tylko kwestia założeń ontologicznych, ale także kwestia ustalenia, które procesy biologiczne mają znaczenie dla trwania fenomenu życia, a to z kolei, w wypadku życia ludzkiego, przynajmniej do pewnego stopnia determinowane jest rozwojem nauk biomedycznych i wynikającą z niego praktyką kliniczną.

Publikacja Polskiego Stowarzyszenia Koordynatorów Transplantacyjnych nosi znamienny tytuł Zrozumieć śmierć człowieka (Łuków, 2015). Tytuł ten znakomicie streszcza istotę problemu - nie chodzi o śmierć organizmu jako takiego ani też o zbudowanie uniwersalnej definicji śmierci, która mogłaby być stosowana do wszystkich organizmów żywych. Kontrowersyjne zagadnienie śmierci dotyczy możliwości opisu specyficznego fenomenu, 
jakim jest śmierć człowieka i uchwycenia go na wszystkich znaczących płaszczyznach: biomedycznej, filozoficznej, społecznej i prawnej. Przenikanie się i wzajemne warunkowanie tych płaszczyzn czyni to zadanie jeszcze trudniejszym, jednak można powiedzieć, że - zgodnie z zachodnią tradycją filozoficzną i współczesną teorią medycyny oraz praktyką kliniczną - całkowita niewydolność mózgu jest osiągnięciem punktu bez powrotu, nawet jeśli zastosowanie aparatury medycznej umożliwi podtrzymanie oddychania i opóźni dezintegrację biologiczną. W warstwie ontologii osoby mamy tu do czynienia ze zmianą o charakterze skokowym, progiem egzystencjalnym oddzielającym „Ja” od ,nie-Ja”. Niezależnie od tego, jak to „nie-Ja” będzie rozumiane - czy jako absolutne „nie-Ja”, czyli nicość, czy też jako „nie-Ja” będące „,innym-Ja" - zawsze będzie ono niebytem w stosunku do osoby, u której stwierdzono całkowitą niewydolność mózgu.

\section{Bibliografia}

White, B. (2014). Another Family Tragedy and Our Collective Losses. Pobrano z: http://www.amc.edu/BioethicsBlog/post.cfm/another-family-tragedy-and-our-collective-losses.

Aviv, R. (2018). What Does It Mean to Die? The New Yorker, 2018.02.05. Pobrano z: https://www.newyorker.com/magazine/2018/02/05/what-does-it-mean-to-die.

Becler, R. (2015). Czy śmierć przychodzi, gdy kończy się życie? W: Zrozumieć śmierć człowieka, red. P. Łuków (s. 51-80). Warszawa: Polskie Stowarzyszenie Koordynatorów Transplantacyjnych.

Belkin, G.S. (2014). Death before Dying. Oxford-New York: Oxford University Press.

Bernat, J.L., Culver, C.M., Gert, B. (1981). On the Definition and Criterion of Death. Annals of Internal Medicine, 94, 389-394.

Bernat J.L. (2002). The Biophilosophical Basis of Whole-Brain Death. Social Philosophy and Policy, 2 (19), 324-342.

Canguilhem, G. (1994). A Vital Rationalist. Selected Writings. Tłum. A. Goldhammer. New York: Zone Books.

Canguilhem, G. (2000). Normalne i patologiczne. Tłum. P. Pieniążek. Gdańsk: słowo/obraz terytoria.

Canguilhem, G. (2012). Writings on Medicine. Tłum. S. Geroulanos, T. Meyers. New York: Fordham University Press. 
Clark, W.R. (2000). Płeć i śmierć. Tłum. A. Alichniewicz, A. Szczęsna. Warszawa: PIW.

Edwards, S.D. (1998). The Body as Object vs. the Body as Subject. Medicine, Health Care and Philosophy, 1 (1), 47-56.

Engelhardt Jr., H.T. (1996). The Foundations of Bioethics. New York-Oxford: Oxford University Press.

Jahi McMath, California Teen at Center of Brain-Death Controversy, Has Died. Pobrano z: https:/edition.cnn.com/2018/06/29/health/jahi-mcmath-brain-dead-teen-death/index.html.

Lee, P. (2016). Total Brain Death and the Integration of the Body Required of a Human Being. Journal of Medicine and Philosophy, 41, 300-314. DOI:10.1093/ jmp/jhw005.

Leder, D. (1990). The Absent Body. Chicago: University of Chicago Press.

Lizza, J.P. (2018). Defining Death: Beyond Biology. Diametros, 55, 1-19.

Łuków, P. (2015). W poszukiwaniu zrozumienia śmierci - etyczne wyzwanie dla lekarzy. W: Zrozumieć śmierć człowieka, red. P. Łuków (s. 13-30). Warszawa: Polskie Stowarzyszenie Koordynatorów Transplantacyjnych.

Marquis, D. (2018). Death Is a Biological Phenomenon. Diametros, 55, 20-26.

Miller, F.G., Truog, R.D. (2012). Death, Dying, and Organ Transplantation. Reconstructing Medical Ethics at the End of Life. Oxford-New York: Oxford University Press.

Nair-Collins, M. (2018). A Biological Theory of Death: Characterization, Justification, and Implications. Diametros, 55, 27-43.

Pernick, M.S. (1988). Back from the Grave: Recurring Controversies over Defining and Diagnosing Death in History. W: Death: Beyond Whole-Brain Criteria, red. R. Zaner (s. 17-74). Dordrecht-Boston-London: Kluwer Academic Publishers.

President's Commission for the Study of Ethical Problems in Medicine and Biomedical and Behavioral Research (1981). Defining Death. Pobrano z: https://repository.library.georgetown.edu/bitstream/handle/10822/559345/defining_death. pdf? sequence $=1 \&$ isAllowed $=\mathrm{y}$.

President's Council of Bioethics (2008). Controversies in the Determination of Death. A White Paper. Pobrano z: https://repository.library.georgetown.edu/bitstream/ handle/10822/559343/Controversies\%20in\%20the\%20Determination \%20 of $\% 20$ Death $\% 20$ for $\% 20$ the $\% 20$ Web.pdf? sequence $=1 \&$ isAllowed $=y$. 
Shewmon, D.A., Shewmon, E.S. (2004). The Semiotics of Death and its Medical Implications. W: Brain Death and Disorders of Consciousness, red. C. Machado, D.A. Shewmon (s. 89-114). New York: Springer.

Singer, P. (1997). Ożyciu i śmierci. Upadek etyki tradycyjnej. Tłum. A. Alichniewicz, A. Szczęsna. Warszawa: PIW.

Truog, R.D. (2018). Defining Death - Making Sense of the Case of Jahi McMath. JAMA, 18 (319), 1859-1860.

Uniform Determination of Death Act (1981). Pobrano z: http://www.lchc.ucsd.edu/ cogn_150/Readings/death_act.pdf.

Veatch, R. (1988). Whole-Brain, Neocortical, and Higher Brain Related Concepts. W: Death: Beyond Whole-Brain Criteria, red. R. Zaner (s. 171-186). Dordrecht-Boston-London: Kluwer Academic Publishers.

Veatch, R. (1993). The Impending Collapse of the Whole-Brain Definition of Death. Hastings Center Report, 4 (23), 18-24.

Zeiler, K. (2009). Self and Other in Global Bioethics: Critical Hermeneutics and the Example of Different Death Concepts. Journal of Medicine and Philosophy, 2 (12), 137-145.

\section{BRAIN DEATH: CONTROVERSIES AND AGREEMENTS}

\section{Summary}

Human death is challenging from both philosophical and medical points of view, because of an apparent ontological discrepancy between the diagnosis of death of the organism as a whole and the declaration of death of a human person. In my paper I make an attempt to analyze the main controversies as well as agreements concerning ontological and medico-epistemological problems that have created the evolution of the definition of brain death, arguing that: 1 . It is impossible to define death; 2 . What functions as the definition of death is rather a set of criteria of death than a definition in a proper sense; 3 . The debate concerning so-called definition of death refers not to death as such, universally conceptualized, but to a specific problem of death of a human being; 4 . Analyzing the problem of human death it is impossible to make a clear distinction between biological and philosophical dimensions. 